\title{
CARRY-OVER OF AFLATOXIN B1-FEED INTO AFLATOXIN M1-MILK IN DAIRY COWS TREATED WITH NATURAL SOURCES OF AFLATOXIN AND BENTONITE
}

\author{
I. Sumantri ${ }^{1,4}$, T.W. Murti ${ }^{1}$, A.F.B. van der Poel ${ }^{2}$, J. Boehm ${ }^{3}$ and A. Agus ${ }^{1}$ \\ ${ }^{1}$ Faculty of Animal Science, Universitas Gadjah Mada, \\ Jl. Fauna No. 3, Bulaksumur Campus, Yogyakarta - Indonesia \\ ${ }^{2}$ Animal Nutrition Group, Wageningen University and Research Centre, \\ Zodiac, De Elst 1, 6700 AH Wageningen - the Netherlands \\ ${ }^{3}$ Institute of Animal Nutrition, Veterinary Medicine, University of Vienna Veterinaerplatz 1 , \\ 1210 Vienna - Austria \\ ${ }^{4}$ Permanent Address: Faculty of Agriculture, Lambung Mangkurat University, \\ Jl. Ahmad Yani Km 36 Banjarbaru - Indonesia \\ CorrespondingE-mail: aliagus@ugm.ac.id
}

Received October 28, 2012; Accepted Novmber 26, 2012

\begin{abstract}
ABSTRAK
Penelitian bertujuan untuk mempelajari karakteristik Carry-over Rate (COR) aflatoksin B1 (AFB1) pakan menjadi aflatoksin M1 (AFM1) susu pada sapi Peranakan Friesian Holstein (PFH) yang mendapatkan pakan terkontaminasi secara alami oleh AFB1 serta inklusi bentonit alam sebagai adsorben. Rancangan penelitian bujur sangkar Latin $4 \times 4$ dilakukan untuk mengetahui pengaruh perlakuan terhadap peubah konsentrasi AFM1 susu, COR, konsumsi nutrien, produksi susu dan komposisi susu. Hasil penelitian memperlihatkan bahwa AFM1 telah dieksresikan pada sampel pemerahan pertama atau sekitar 10 jam setelah ternak mengkonsumsi pakan mengandung AFB1. Ekskresi AFM1 susu pada konsentrasi yang konstan teramati sejak hari pertama periode perlakuan dan cemaran AFM1 masih ditemukan hingga hari ke 5 setelah ternak tidak mendapatkan perlakuan. Pada penelitian ini diperoleh nilai COR sebesar $0,1 \%$. Konsentrasi AFM1 sangat dipengaruhi $(\mathrm{P}<0,01)$ oleh perlakuan, meskipun demikian tidak berpengaruh nyata $(\mathrm{P}>0,05)$ terhadap nilai $\mathrm{COR}$, konsumsi nutrien, serta produksi dan komposisi susu. Disimpulkan bahwa konsentrasi AFM1 susu dipengaruhi oleh tingkat konsumsi AFB1 pakan dan COR pada sapi PFH lebih rendah dibandingkan nilai COR yang dilaporkan oleh peneliti sebelumnya untuk sapi perah di daerah sub tropis.
\end{abstract}

Kata kunci: Aflatoksin B1, aflatoksin M1, carry-over rate aflatoxin, pakan tercemar AFB1

\begin{abstract}
High occurrence of aflatoxin contamination in feed stuffs implicates for a long time experience of aflatoxin B1 (AFB1) exposure to dairy cattle in Indonesia. A latin square 4X4 research design was adopted to study the characteristic of AFB1 carry-over rate (COR) of Indonesian crossbred Friesian Holstein (PFH) as effects of inclusions of AFB1-naturally contaminated feed and bentonite in the diet. Results showed a rapid aflatoxin M1 (AFM1) excretion in the milk, detected in the first milking sample or 10 hours after AFB1 ingestion. The steady state of AFM1 concentration observed since the first day of treatment period and AFM1 contamination was still detected until 5 days after AFB1 removed from the diet. The COR in this study was observed $0.1 \%$. AFM1 concentration was highly significantly $(\mathrm{P}<0.01)$ affected by treatments. However, there were no significant effects $(\mathrm{P}>0.05)$ of levels of AFB1 and bentonite inclusions on the COR, nutrients intake, milk production, and milk composition. IIt is concluded that AFM1 concentration was influenced by AFB1 intake and that transfer of AFB1-feed into AFM1-milk (COR) in PFH cow was lower compare to reported COR value for dairy cow in sub tropical region.
\end{abstract}

Keywords: Aflatoxin B1, aflatoxin M1, carry-over rate of aflatoxin, AFB1-contaminated feed 


\section{INTRODUCTION}

High ambient temperatures and high relative humidity in tropical regions, such as in Indonesia, are very conducive for the development of certain fungus to produce mycotoxins (Bryden, 2012). Aflatoxin B1 (AFB1) was recognised as the most toxic mycotoxins and International Agency for Research on Cancer (IARC) has classified AFB1 as Group 1 human carcinogen (IARC, 2002). Liu and $\mathrm{Wu}(2010)$ estimated that aflatoxin exposure may contribute to $28.2 \%$ of all liver cancer case in the worldwide.

Since AFB1 in feed can be transferred into the milk as its hydroxylated metabolite, aflatoxin M1 (AFM1), the carry-over of AFB1 from contaminated feed into milk has been a special interest and is regulated for feed in many countries worldwide (Voelkel et al., 2011). Testing in animal laboratory indicated that AFM1 has a similar toxicity and carcinogenicity to AFB1 (Van Egmond, 1989). The presence of AFM1 in milk and the consumption of milk and milk products are then the principal ways by which aflatoxin is introduced to the human diet (Galvano et al., 1998; Mohammadi, 2011).

Previous studies indicated high occurrence and levels of AFB1 contamination in Indonesian feed ingredients and feedstuffs for dairy cow (Ali et al., 1998; Goto et al., 1999; Pitt and Hocking, 2004). Survey by Nuryono et al. (2009) revealed that $100 \%$ of fresh milk samples from Yogyakarta province were contaminated by AFM1. However, none of contaminated samples exceeded the European Union regulation limits of $25 \mathrm{ng}$ and 50 ng AFM1/L for infant and adult consumption, respectively. A preliminary research by Agus et al. (2010) calculated the CORs of PFH cows fed by different levels of AFB1 in the diet were ranging from $0.08 \%$ to $0.20 \%$. This COR value was lower compared to the previous studies for sub tropical lactating dairy cow that was ranging from $1 \%$ to 3\% (Diaz et. al., 2004; Van Eijkeren et al., 2006; Masoero et al., 2007). It is less known whether long time exposure to AFB1 contaminated feed results in adaptation of $\mathrm{PFH}$ cows to detoxify AFB1.

Carry-over aflatoxin into milk can be reduced by in vivo chemisorptions (Volkel et al., 2011). The addition of adsorbents in the diet is the most recent approaches and widely applied way to prevent mycotoxicosis in the livestock. Several adsorbents posses' high affinity to AFB1, such as activated carbons, zeolites, bentonites, and certain clays may bind $\mathrm{AFB} 1$ in the gastrointestinal tract and reduce its bioavailability (Kabak et al., 2006). The aims of this study were to determine the characteristics of COR of PFH cow after consumed different levels of natural sources of $\mathrm{AFB} 1$ and inclusion of an in vitro effective AFB1 adsorbent, namely bentonite, in the diet.

\section{MATERIALS AND METHODS}

The experiment was carried out in the research facilities of Universitas Gadjah Mada Yogyakarta, Indonesia. Four lactating PFH cows, which were in 12-14 weeks of postpartum and had the average body weight of $380 \mathrm{~kg}$, were used in the trial. Naturally AFB1-contaminated ground peanut meal was used as source of AFB1. ELISA test showed that the ground peanut meal was containing AFB1 at $1358 \mu \mathrm{g} / \mathrm{kg}$. AFB1-free ground peanut could not be found in such amount, therefore a batch of naturally low contaminated ground peanut were used as control for a low daily intake of AFB1. ELISA test indicated that the low contaminated ground peanut meal contained AFB1 at $13 \mu \mathrm{g} / \mathrm{kg}$. The high daily intake of AFB1 was referred at two times of AFB1 inclusion in the study of AFB1 carry over by Masoero et al. (2009) which was 175 $\mu \mathrm{g} /$ cow/day or equal to $350 \mu \mathrm{g} \mathrm{AFB1/cow/day} \mathrm{in}$ this study. The amount of high contaminated ground peanut meal inclusion in the diet was calculated as the desired level of AFB1 intake ( $350 \mu \mathrm{g} / \mathrm{cow} /$ day) divided by $\mathrm{AFB}_{1}$ content in the high contaminated ground peanut $(1358 \mu \mathrm{g} / \mathrm{kg})$ that was equal to $0.258 \mathrm{~kg}$ high contaminated ground peanut meal/cow/day. At the same amount of peanut meal inclusion, the low AFB1 intake diet served $3.41 \mu \mathrm{g} \mathrm{AFB}_{1} / \mathrm{cow} /$ day. The ration composition of each treatment is presented in the Table 1. Thus, the treatments were: (1) T1: a ration with low dose of AFB1 (3.4 $\mu \mathrm{g}$ AFB1/cow/day) without bentonite inclusion; (2) T2: a ration with high dose of AFB1 $(350 \mu \mathrm{g}$ AFB1/cow/day) without bentonite inclusion; (3) T3: a ration with high dose of AFB1 (350 $\mu \mathrm{g}$ AFB1/cow/day) and low dose of bentonite inclusion $(0.25 \%$ of the dry matter (DM) weight of concentrate feed); and (4) T4: a ration with high dose of AFB1 (350 $\mu \mathrm{g}$ AFB1/cow/day) and high dose of bentonite inclusion (2.0\% of the DM weight of concentrate feed).

The experiment used a Latin square $4 \times 4$ research design consisted of four 15-days period. 
Each experimental period was consisted of $5 \mathrm{~d}$ for adaptation followed by sample collection period from d 6 to 10 , then lasted by clearing period from d 11 to 15 . The first period was also designed as the preliminary study for the pattern of AFM1 excretion in PFH cows, therefore the milk samples were collected for all days in the first period (d 1 to 15 ).

The observed variables were nutrients intake (Dry Matter/DM and Organic Matter/OM), AFM1 content, COR, milk production, and milk composition (total solids, milk fat, and milk protein). Determinations of DM and OM were carried out based on the proximate analysis procedure (AOAC, 1984). Dry Matter and OM intakes, then, were calculated based on feed intake data. Cows were milked twice a day (morning and afternoon). Milk production for each milking time was recorded individually and sampled for determination of milk composition. Samples were composited for each day based on proportion of production in every milking then stored at $-18^{\circ} \mathrm{C}$ in the freezer. Milk compositions (fat, protein, and total solid) were analyzed according to AOAC (1984).

ELISA tests were carried out to analyze the contents of AFB1 in feed and AFM1 in milk sample. The tests were performed using different ELISA kits those were Ridascreen ${ }^{\circledR}$ Aflatoxin B1 30/15 and Ridascreen ${ }^{\circledR}$ Aflatoxin M1 30/15 RBiopharm AG, Germany. The carry-over of AFB1 feed to AFM1 milk then was calculated based on the amount of AFB1 intake and AFM1 excretion in all of the 4 periods using the following formula:

Carry 0ver Rate $=\frac{\operatorname{AFM1}\left(\frac{\mathrm{ng}}{\mathrm{kg}}\right) \times \text { milk production }\left(\frac{\frac{\mathrm{kg}}{\mathrm{cow}}}{\text { day }}\right)}{\operatorname{AFB} 1 \text { intake }\left(\frac{\frac{\mathrm{ng}}{\mathrm{cow}}}{\mathrm{day}}\right)} \times 100 \%$

Data was statistically analyzed by analysis of variance using the general linear model of SPSS version 17.0.

\section{RESULTS AND DISCUSSION}

The preliminary study showed that AFM1 was detected in the first milk sample after AFB1 ingestion or approximately 10 hours after AFB1 ingestion. This result confirmed the rapid excretion of AFB1 metabolite in milk according to Diaz et al. (2004) and Masoero et al. (2007). Aflatoxins are rapidly absorbed through membranes by a passive mechanism due to its low molecular weight, namely 312.27 and 328.27 Dalton for AFB1 and AFM1 respectively (Yiannikouris and Jouany, 2002). The AFM1 in blood plasma was detected less than 15 minute after AFB1 intake (Moschini et al., 2008).

As shown in the Figure 1, the increment of AFM1 was dramatically increase since the first day and remained in the relatively similar level until 5 days after AFB1 was removed from the diet. This pattern of AFM1 excretion established a plateau of AFM1 concentration from initial of AFB1 ingestion. These results were partially conflicting to previous reports that concluded a steady state was reached in 2-3 days after treatment and AFM1 declined to a zero concentration in less than 3 days after the cow was fed with an AFB1-free diet (Van Egmond, 1989; Diaz et al., 2004; Masoero et al., 2007). However this study was in agreement with result reported by Frobish et al. (1996) in which the steady state of AFM1 excretion was established at $24 \mathrm{~h}$ from initial AFB1 ingestion.

Table 2 shows that Aflatoxin M1 concentration was significantly lower in the low dose of AFB1 treatment compared to the high dose (8.8 vs 58.6; 57.6; and $53.0 \mathrm{ng} / \mathrm{kg}$ ). However, the COR was not significantly affected by the treatments. Volkel et al. (2011) concluded that COR was not directly influenced by the doses administered although the absolute amount of AFM1 excreted was dependent on AFB1 intake per $\mathrm{kg}$ body weight. Carry-over rate of AFB1 in this study $(0.1 \%)$ was much lower compared to other studies that were ranging from 1 to $3 \%$ (Diaz et al., 2004; Van Eijkeren et al., 2006; Masoero et al., 2007). Variation on COR can be observed due to differences in the animal species (Battacone et al., 2003), stage of lactation (Veldman et al., 1992), milk yield (Masoero et al., 2007), and individual variability (Van Egmond, 1989).

In this study, bentonite inclusion had no significant effect to reduce the concentration of AFM1 in milk. In vitro binding capacity of AFB1 adsorbents has not always been comparable to in vivo responses. Some factors are important to affect on the efficacy of AFB1 adsorbents, such as the ratio AFB1 to the adsorbent, $\mathrm{pH}$, temperature, and the biological aspects of the fluid (Moschini et al., 2008). According to Jaynes et al. (2007), the effectiveness of clay as an adsorbent for mycotoxins was influenced by its adsorption mechanism and clay properties, i.e. bentonite 
Tabel 3. Ingredient and Chemical Composition of Treatment Diet

\begin{tabular}{lcccc}
\hline & \multicolumn{4}{c}{ Treatments } \\
\cline { 2 - 5 } & \multicolumn{2}{c}{$\mathrm{T} 1$} & $\mathrm{~T} 2$ & $\mathrm{~T} 4$ \\
\hline Ingredients: & & & & \\
Napier grass (kg DM) & 6.84 & 6.84 & 6.84 & 6.84 \\
Pollard (kg DM) & 4.56 & 4.56 & 4.56 & 4.56 \\
Highly AFB1 contaminated peanut meal (kg DM) & 0.000 & 0.258 & 0.258 & 0.258 \\
Low AFB1 contaminated peanut meal (kg DM) & 0.258 & 0.258 & 0.258 & 0.258 \\
Bentonite (g) & 0.000 & 0.000 & 7.525 & 60.200 \\
Chemical composition: & & & & \\
Crude protein $(\%)$ & 16 & 16 & 16 & 16 \\
Ca (\%) & 1.0 & 1.0 & 1.0 & 1.0 \\
P (\%) & 0.5 & 0.5 & 0.5 & 0.5 \\
Calculated: & 5 & & & 5 \\
NEL (MJ/kg) & 5 & 5 & 5 & 5 \\
Bentonite $(\%$ DM of concentrate feed) & 0.00 & 0.00 & 0.25 & 2.00 \\
AFB1 content $(\mu \mathrm{g})$ & 3.4 & 350.0 & 350.0 & 350.0 \\
\hline
\end{tabular}

T1: a ration with low dose of AFB1 (3.4 $\mu \mathrm{g} \mathrm{AFB} 1 /$ cow/day) without bentonite inclusion; T2: a ration with high dose of AFB1 (350 $\mu \mathrm{g}$ AFB1/cow/day) without bentonite inclusion; T3: a ration with high dose of AFB1 (350 $\mu \mathrm{g}$ AFB1/cow/day) and low dose of bentonite inclusion ( $0.25 \%$ of the dry matter (DM) weight of concentrate feed); T4: a ration with high dose of AFB1 (350 $\mu \mathrm{g} \mathrm{AFB} 1 / \mathrm{cow} / \mathrm{day})$ and high dose of bentonite inclusion $(2.0 \%$ of the DM weight of concentrate feed).

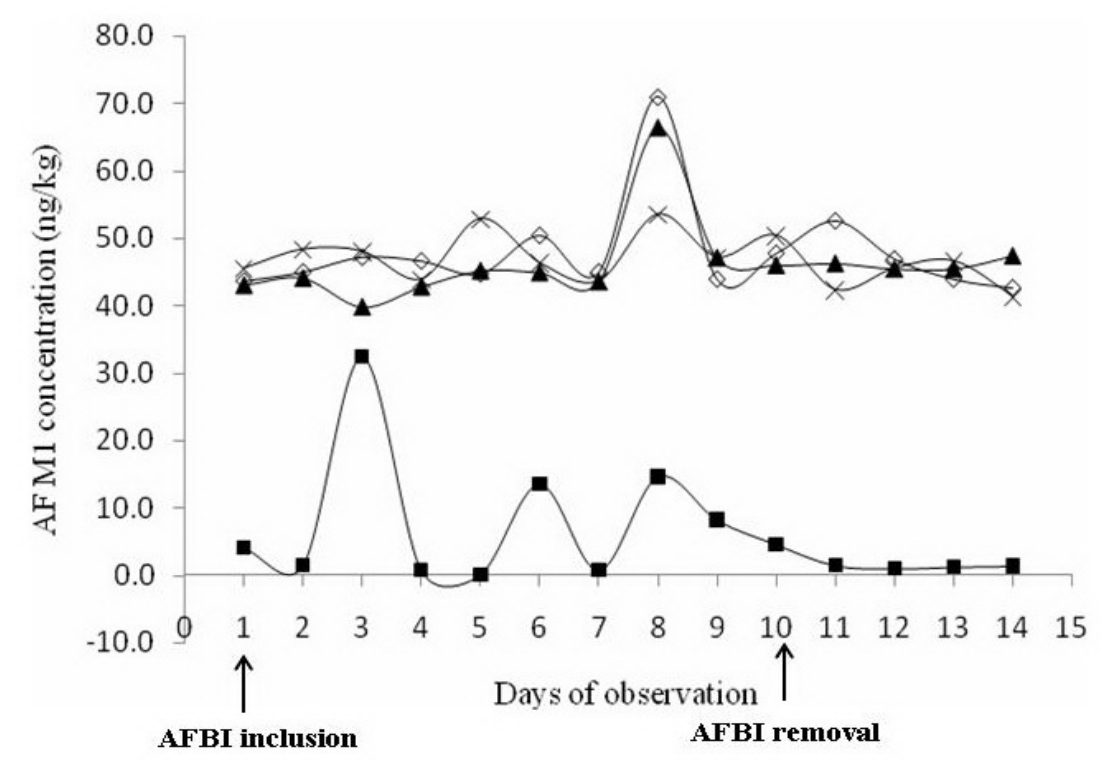

Figure 1. AFM1 Concentration (ng/kg) in the Cows Consuming Different Treatment Diet. The Symbols Represent T1 (घ), T2 (৩), T3 ( $\mathbf{\Delta})$, and T4 (×). 
Table 2. The Effects of Treatment Diet on Observed Variables

\begin{tabular}{|c|c|c|c|c|}
\hline \multirow{2}{*}{ Variable } & \multicolumn{4}{|c|}{ Treatment } \\
\hline & $\mathrm{T} 1$ & $\mathrm{~T} 2$ & $\mathrm{~T} 3$ & $\mathrm{~T} 4$ \\
\hline AFM1 concentration (ng/kg) & $8.8 \pm 6.52^{\mathrm{a}}$ & $58.6 \pm 10.00^{\mathrm{b}}$ & $57.6 \pm 7.79^{\mathrm{b}}$ & $53.0 \pm 1.97^{\mathrm{b}}$ \\
\hline Carry-over rate $(\%)^{\mathrm{ns}}$ & $0.12 \pm 0.087$ & $0.10 \pm 0.011$ & $0.10 \pm 0.011$ & $0.10 \pm 0.004$ \\
\hline Dry matter intake $(\mathrm{kg} / \mathrm{cow} / \text { day })^{\mathrm{ns}}$ & $11.22 \pm 1.64$ & $11.43 \pm 1.85$ & $11.36 \pm 1.88$ & $11.42 \pm 1.10$ \\
\hline Organic matter intake (kg/cow/day) ${ }^{\mathrm{ns}}$ & $10.24 \pm 1.41$ & $10.41 \pm 1.59$ & $10.36 \pm 1.61$ & $10.42 \pm 0.95$ \\
\hline Milk production $(\mathrm{kg} / \mathrm{cow} / \text { day })^{\mathrm{ns}}$ & $6.75 \pm 0.43$ & $6.72 \pm 0.89$ & $6.85 \pm 1.31$ & $7.27 \pm 0.30$ \\
\hline Milk fat $(\%)^{\text {ns }}$ & $2.96 \pm 0.25$ & $3.30 \pm 0.45$ & $2.74 \pm 0.57$ & $3.18 \pm 0.39$ \\
\hline Milk protein $(\%)^{\mathrm{ns}}$ & $3.31 \pm 0.39$ & $3.22 \pm 0.17$ & $3.28 \pm 0.16$ & $3.20 \pm 0.15$ \\
\hline Total solid (\%) ${ }^{\mathrm{ns}}$ & $11.89 \pm 0.94$ & $11.98 \pm 0.91$ & $11.90 \pm 0.88$ & $11.75 \pm 0.45$ \\
\hline
\end{tabular}

${ }^{\mathrm{ab}}$ Means within a row with different superscript differ highly significant $(\mathrm{P}<0.01)$

${ }^{n s}$ Non significant $(\mathrm{P}>0.05)$

could adsorb 100\% AFB1 initially present in aqueous solution. Thus, when bentonite is added to dry feed, the AFB1 adsorption to bentonite must occur after ingestion.

Levels of AFB1 intake and bentonite inclusion had no significant effect on DM and OM intakes, milk production, and milk composition (Table 2). Statistical analysis indicated that differences in the milk production and a milk component, namely total solids, were rather affected by cow and treatment period. Treatments by mean levels of AFB1 and adsorbent in this study were apparently still lower than the doses that were used in the previous studies. Effects of AFB1 treatment to the milk yield were observed in the high intake of AFB1 $(100-300 \mu \mathrm{g} / \mathrm{kg} \mathrm{BW})$, such as study by Patterson and Anderson (1982) and Mertens and Wyatt (1977). These studies showed that decrease in milk yield was a direct or an indirect result of decreased in feed intake. High dose of AFB1 inclusion affected liver damage and consequence on decreasing in feed intake and milk production. Similar results to our study were obtained by Applebaum et al. (1982) that at low level of AFB1 contamination used in the trial $(0.16 \mathrm{mg} / \mathrm{kg} \mathrm{BW})$, there was no effect in milk yield pattern during the AFB1 ingestion period. This result suggested that a threshold level of AFB1 contamination for a depression in milk yield might be around $100 \mathrm{mg}$ AFB1 per kg BW.

\section{CONCLUSION}

AFM1 was detected at the first milk sample or 10 hours after AFB1 ingestion. The steady state of AFM1 concentration was observed since the $1^{\text {st }}$ day of treatment period and AFM1 contamination was still detected until 5 days after AFB1 was removed from the diet. The carry-over rate of Indonesian crossbred Friesian Holstein (PFH) was observed $0.1 \%$ and that was lower compared to COR value reported in other studies. Aflatoxin M1 concentration was significantly affected by AFB1 doses. However, there were no significant effects of AFB1 levels and bentonite inclusions on the COR, nutrients intakes, milk production, and milk composition.

\section{REFERENCES}

Agus, A., I. Khuluq, I. Sumantri, C.T. Noviandi and Nuryono. 2010. Aflatoxin M1 excretion in the milk of tropical dairy cow fed contaminated aflatoxin B1 in the diet. Proceeding, the $5^{\text {th }}$ International Seminar on Tropical Animal Production, Faculty of Animal Science, Universitas Gadjah Mada, Yogyakarta, Indonesia, 19th-22nd October, 2010. P. 282-285

Ali, N., Sardjono, A. Yamashita and T. Yoshizawa. 1998. Natural co-occurrence of aflatoxins and Fusavium mycotoxins (fumonisins, 
deoxynivalenol, nivalenol and zearalenone) in corn from Indonesia. Food Addit. Contam. 15(4):377-384

AOAC, 1984. Official Methods of Analysis of the Association of Official Analytical Chemists. $14^{\text {th }}$ Edition. AOAC Inc.

Applebaum, R.S., R.E. Brackett, D.W. Wiseman and E.H. Marth. 1982. Responses of dairy cows to dietary aflatoxin: feed intake and yield, toxin content, and quality of milk of cows treated with pure and impure aflatoxin. J. Dairy Sci. 65:1503-1508

Battacone, G., A. Nudda, A. Cannas, A. Cappio, B. Borlino, G. Bomboi and G. Pulina. 2003. Excretion of aflatoxin M1 in milk of dairy ewes treated with different doses of aflatoxin B1. J. Dairy Sci. 86:2667-2675

Bryden, W.L. 2012. Mycotoxin contamination of the feed supply chain: implications for animal productivity and feed security. Anim. Feed Sci. Technol. 173:134-158

Diaz, D.E., W.M. Hagler, J.T. Blackwelder, J.A. Eve, B.A. Hopkins, K.L. Anderson, F.T. Jones and L.W. Whitlow. 2004. Aflatoxin binders II: reduction of aflatoxin $M_{1}$ in milk by sequestering agents of cows consuming aflatoxin in feed. Mycopathologia 157: 233241

Frobish R.A., B.D. Bradley, D.D. Wagner, P.E. Long-Bradley and H. Hairston. 1986. Aflatoxin residues in milk of dairy cows after ingestion of naturally contaminated grain. $\mathrm{J}$. Food Prot. 49:781-785

Galvano, F., V. Galofaro, A. De Angelis, M. Galvano, M. Bognanno and G. Galvano. 1998. Survey of the occurrence of aflatoxin M1 in dairy products marketed in Italy. J. Food Prot. 61:738-741

Goto, T., E. Ginting, S.S. Antarlina, J.S. Utomo, Y. Ito and S. Nikkuni. 1999. Aflatoxin contamination and fungi isolated from Indonesian agricultural commodities. Proceeding, International Symposium of Mycotoxicology, Chiba University, Chiba, Japan, 9th-10th September 1999. P. 211-215

IARC (International Agency for Research on Cancer), 2002. Some traditional herbal medicines, some mycotoxins, napthalene and styrene. IARC Monogr. Eval. of Carcinog. Risks Hum. 82:171-300

Jaynes, W.F., R.E. Zartman and W.H. Hudnall. 2007. Aflatoxin B1 adsorption by clays from water and corn meal. App. Clay Sci. 36:197-

\section{5}

Kabak, B., A.D.W. Dobson and I. Var. 2006. Strategies to prevent mycotoxin contamination of food and animal feed: A review. Crit. Rev. Food Sci. Nutr. 46(8):593619

Liu, Y. and F. Wu. 2010. Global burden of aflatoxin-induced hepatocellular carcinoma: a risk assessment. Environ. Health Perspect. 118(6):818-824

Masoero, F., A. Gallo, M. Moschini, G. Piva and D. Diaz. 2007. Carryover of aflatoxin from feed to milk in dairy cows with low or high somatic cell counts. Animal 1: 1344-1350.

Masoero, F., A. Gallo, D. Diaz, G. Piva and M. Moschini. 2009. Effects of the procedure of inclusion of a sequestering agent in the total mixed ration on proportional aflatoxin M1 excretion into milk of lactating dairy cows. Anim. Feed Sci. Technol. 150(1):34-45

Mertens, D.R. and R.D. Wyatt. 1977. Acute aflatoxicosis in lactating dairy cows. J. Dairy Sci. 60 (Suppl. 1):153-154

Mohammadi, H. 2011. A review of Aflatoxin M1, Milk, and Milk products. In: R. G. GuevaraGonzalez (Ed.). Aflatoxins-Biochemistry and Molecular Biology. Intech. Rijeka. P.:397414.

Moschini, M., A. Gallo, G. Piva and F. Masoero. 2008. The effects of rumen fluid on the in vitro aflatoxin binding capacity of different sequestering agents and in vivo release of the sequestered toxin. Anim. Feed Sci. Technol. 147:292-309

Nuryono, N., A. Agus, S. Wedhastri, Y. B. Maryudani, F. M. C. Sigitsetyabudi, J. Bohm and E. Razzazi-Fazeli. 2009. A limited survey of aflatoxin $M_{1}$ in milk from Indonesia by ELISA. Food Control 2:721724

Patterson, D.S.P. and P.H. Anderson. 1982. Recent aflatoxin feeding experiments in cattle. Vet. Rec. 110:60-61

Pitt, I. I. and A. D. Hocking. 2004. Current mycotoxin issues in Australia and Southeast Asia. In: D. Barug, H. P. Van Egmond, R. Lopez-Garcia, T. Van Ossenbruggen and A. Visconti (Eds.). Meeting the Mycotoxin Menace. Wageningen Academic Publishing. Wageningen. P.69-80

Van Egmond, H.P. 1989. Aflatoxin M1: occurrence, toxicity, regulation. In: H.P. Van Egmond (Ed.). Mycotoxin in Dairy Elsevier 
Applied Science. London. P.11-55

Van Eijkeren, J.C.H., M.I. Bakker and H.J. Zeilmaker. 2006. A simple steady-state model for carry-over of aflatoxins from feed to cow's milk. Food Addit. Contam. 23(8):833-838

Veldman, A. 1992. Effect of sorbentia on carryover of aflatoxin from cow feed to milk. Milchwissenschaft. 47: 777-780
Volkel, I., E. Schroer-Merker and C.P. Czerny. 2011. The carry-over of mycotoxins in products of animal origin with special regards to its implications for the European food safety legislation. Food Nutr. Sci. 2:852-867

Yiannikouris, A. and J.P. Jouany, J.P. 2002. Mycotoxins in feeds and their fate in animals: a review. Anim. Res. 51:81-99 